\title{
First record of the bushy-tailed opossum, Glironia venusta, Thomas, 1912, (Didelphimorphia) from Manaus, Amazonas, Brazil
}

\author{
Javier CALZADA ${ }^{\text {, Miguel DELIBES }}{ }^{2}$, Claudia KELLER ${ }^{3}$, Francisco PALOMARES ${ }^{4}$, William MAGNUSSON ${ }^{5}$
}

\section{ABSTRACT}

A new record of a very rarely observed mammal, the bushy-tailed opossum, Glironia venusta (Didelphimorphia), was obtained for the Adolpho Ducke Forest Reserve, Manaus, Amazonas state, Brazil. Only 17 other records existed of this species, most from the 1980s. There were only three previous records of the species from Brazil (in the states of Pará, Amazonas and Rondônia). This new record supports the notion that G. venusta is a locally rare species throughout its range, but widely distributed in Brazilian Amazonia.

KEYWORDS: Amazon, Bushy-tailed opossum, Didelphidae, Didelphimorphia, Glironia venusta.

\section{Primeiro registro de Glironia venusta, Thomas, 1912 (Didelphimorphia) em Manaus, Amazonas, Brazil}

\section{RESUMO}

Um indivíduo de Glironia venusta (Didelphimorphia), foi observado na Reserva Florestal Adolpho Ducke, Manaus, Amazonas, Brasil. Existem apenas 17 outros registros publicados desta espécie de marsupial, a maioria da década de 80. No Brasil, G. venusta havia sido registrada em três outras localidades, no Pará, Amazonas e Rondônia. Com este registro em uma das áreas mais intensivamente estudadas na Amazônia, ganha reforço a noção de que G. venusta é uma espécie rara localmente, mas de ampla distribuição na Amazônia brasileira.

PALAVRAS-CHAVE: Amazonas, Didelphidae, Didelphimorphia, Glironia venusta.

\footnotetext{
1 Departamento de Biología Ambiental y Salud Pública. Universidad de Huelva. e-mail: javier.calzada@dbasp.uhu.es

2 Estación Biológica de Doñana, CSIC. España. e-mail: mdelibes@ebd.csic.es

3 Instituto Nacional de Pesquisas da Amazônia, Coordenação de Pesquisas em Ecologia, CPEC/INPA, Av. André Araújo, 2936, Aleixo, CEP 69060-001, Manaus - AM, Fone: (92) 3643-3377. keller@inpa.gov.br

${ }^{4}$ Estación Biológica de Doñana, CSIC. España. e-mail: ffpaloma@ebd.csic.es

${ }^{5}$ Instituto Nacional de Pesquisas da Amazônia, Coordenação de Pesquisas em Ecologia, CPEC/INPA. Av. André Araújo, 2936, Aleixo, CEP 69060-001, Manaus - AM, Fone: (92) 3643-3377. e-mail: bill@inpa.gov.br
} 
On 21 July 2004, at 19:38 solar time, a bushy-tailed opossum, G. venusta, was observed in the Adolpho Ducke Forest Reserve (RFAD; 02055' S, 5959’ W), a Terra-firme rainforest reserve located on the outskirts of the city of Manaus (Amazonas state, Brazil). Individuals of this species have been recorded only at 17 other localities, with records from Bolivia, Peru, Ecuador and Brazil (Marshall 1978; Brown 2004; Díaz \& Willig, 2004). Previous records of the species in Brazil were made at (1) the mouth of the Mapuera river, Cachoeira Porteira village, Pará state (Da Silva \& Langguth, 1989); (2) the upper Urucu River, Amazonas state (unpublished record of Ferreira da Silva in 1989, Tarifa and Anderson 1997); and (3) Espigão do Oeste, Rondonia state (Bernardé \& Rocha, 2003). The present record was made in undisturbed forest, at an altitude of 86 m.a.s.l., approximately $15 \mathrm{~km}$ from the margin of the Amazonas river and approximately $3 \mathrm{~km}$ from the nearest area of human impact.

The bushy-tailed opossum was seen by two of us simultaneously during a nocturnal transect survey of vertebrates in the RFAD. Walking speed was approximately $1 \mathrm{~km} /$ hour, observation equipment included bird binoculars, halogen headlamps and portable halogen spotlights.

The animal was observed during 20 minutes in vines hanging from a large tree, at approximately $15 \mathrm{~m}$ height. Head-body length was estimated as $15-20 \mathrm{~cm}$ (visual estimation), and tail length was similar to head-body length. Dorsal coloration was uniform, from brownish to grey, but the head was paler with a broad black stripe from the nose through the eye and to the crown of the head. The tail had the same color as the body, and appeared to be furred to the tip. The tail tip had a paler tone, but we were not able to distinguish whether it was a color change in the fur or if the very tip of the tail had no fur.

Although lacking a collected specimen or a photograph we argue that this observation is a reliable record, because of the unmistakeable morphological and behavioural traits that characterize G. venusta. No other New World marsupial species has an almost fully furred tail except the black-shouldered opossum, Caluromysiops irrupta, which, is larger and grey with large black patches across the shoulders (Emmons \& Feer, 1997), and probably not present in the RFAD (Díaz \& Willig, 2004). No other New World marsupial has similar facial stripes (Emmons \& Feer, 1997). The animal we observed also behaved differently from other opossums seen in the area during our nocturnal surveys (common opossum, Didelphis marsupialis, and common grey four-eyed opossum, Philander opossum), which normally remained still once spotted. In accordance with the observations of Emmons \& Feer (1997) for bushy-tailed opossums, the animal we observed moved rapidly and nervously among vines, climbing up and down the tree, with short stops during which it kept looking at us. Sometimes it hid from our lights on the opposite side of the tree, reappearing again after a few seconds. Downward movements were headfirst, not using the tail. It did not remain still for long, but did not try to run away from us. The opossum stayed on the same tree until we left.

The RFAD belongs to the National Institute for Research in the Amazon (INPA) and is one of the most studied Amazonian rainforest sites since the 1960s. However, until, 2000 , all research in the reserve was restricted to approximately $20 \%$ of its 10000 ha area. In 2000 a trail system in the form of a $64 \mathrm{~m}^{2} 1 \mathrm{x} 1-\mathrm{km}$-grid was installed by the "Programa de Pesquisas Ecológicas de Longa Duração" (PELD), which opened up the whole area for research. Since then, the "Programa de Pesquisa em Biodiversidade" (PPBio) has supported extensive research, and several new species have been registered, including amphibians, palms, understory plants, harpy eagles, and lizards (Costa et al., 2005; Kinupp \& Magnusson, 2005; Pinto, 2006; Mosquera et al., 2006; Menin et al., 2007, 2006). It is noteworthy, however, that a relatively large tree-dwelling vertebrate like the bushy-tailed opossum went unnoticed until now. The RFAD is in close contact with urban areas of Manaus and, in at least two other records in Brazil and Peru (Da Silva \& Langguth, 1989; Díaz $\&$ Willig, 2004), this species was found in or close to human impacted areas, suggesting that it does not avoid proximity to human settlements.

These results support the notion that $G$. venusta is a locally rare species throughout its range. The present location lies roughly between two of the previous ones in Brazil (upper Urucu river and mouth of the Mapuera river), confirming the presence of the species in central Amazonia.

\section{ACKNOWLEDGMENTS}

Fieldwork was supported by CSIC/CNPq (CSIC project \# 2004BR0009 and CNPq project \# 690065/02-8) and INPA/PPI \#1-3650. The PELD program is supported by the Conselho Nacional de Desenvolvimento Científico e Tecnológico (CNPq) and the PPBio program by the Ministry of Science and Technology (MCT). We thank specially Ana Píriz and Marta Sánchez for help in the field. Research in Brazil was authorized by $\mathrm{CNPq} / \mathrm{CMC} 042 / 03$ - Portaria MCT n ${ }^{\circ} 282 / 04$.

\section{LETERATURE CITED}

Bernarde, P.H.; Rocha, V.A. 2003. New record of Glironia venusta Thomas, 1912 (Mammalia, Glironiidae) for the State of Rondônia-Brazil. Biociências 11(2): 183-184.

Brown, B.E. 2004. Atlas of New World Marsupials. Field Museum of Natural History. Fieldiana Zoology, New Series 102. Chicago, USA. 308pp. 


\section{ACTA}

Costa, F.R.C.; Magnusson, W.E.; Luizão, R.C. 2005. Mesoscale distribution patterns of Amazonian understorey herbs in relation to topography, soil and watersheds. Journal of Ecology, 93: 863-878.

Da Silva, M.N.F.; Langguth, A. 1989. A New Record of Glironia venusta from the Lower Amazon, Brazil. Journal of Mammalogy, 70: 873-875.

Díaz, M.M.; Willig, M.R. 2004. Nuevos registros de Glironia venusta y Didelphis albiventris (Didelphimorphia) para Perú. Mastozoología Neotropical, 11: 185-192.

Emmons, L.H.; Feer, F. 1997. Neotropical Rainforest Mammals. The University of Chicago Press. Chicago, USA. 307pp.

Kinupp, V.F.; Magnusson, W.E. 2005. Spatial patterns in the understorey shrub genus Psychotria in central Amazonia: effects of distance and topography. Journal of Tropical Ecology, 21: 363-374.

Marshall, L.G. 1978. Glironia venusta. Mammalian Species, 107: $1-3$.

Menin, M.; Lima, A.P.; Magnusson, W.E.; Waldez, F. 2007. Topographic and edaphic effects on the distribution of terrestrially reproducing anurans in Central Amazonia: mesoscale spatial patterns. Journal of Tropical Ecology, 23: 539-547.
Mosquera, R.; Albuquerque, J.; Piana, R.; Thiollay, J.M.; Marquez, C.; Sanchez, J.E.; Lopez, M.L.; Midence, S.; Matola, S.; Aguilar, S.; Retting, N.; Sanaiotti, T.M. 2006. Estado y distribución actual del árgila arpia (Harpia harpyja) en centro y sur América. Ornitología Neotropical, 17: 39-55.

Pinto, M.G.M. 2006. Diversidade beta, métodos de amostragem e influência de fatores ambientais sobre uma comunidade de lagartos na Amazônia Central. PhD thesis. Instituto Nacional de Pesquisas da Amazônia. 75pp.

Tarifa, T.; Anderson, S. 1997. Two additional records of Glironia venusta Thomas, 1912 (Marsupialia, Didelphidae) for Bolivia. Mammalia, 61: 111-113.

Recebido em 23/11/2007

Aceito em 07/05/2008 
